\title{
Female terminalia of Tabanidae (Diptera) from Japan
}

\author{
Kusuo IWATA and Akira NAGATOMI \\ * Department of Parasitology, School of Medicine, Fukuoka University, \\ Fukuoka 814 \\ ** Entomological Laboratory, Faculty of Agriculture, Kagoshima University, \\ Kagoshima 890
}

(Received: October 8, 1975)

\begin{abstract}
This paper describes and illustrates the female terminalia of the Tabanidae known from Japan and deals with the following genera: Stonemyia (1 species), Nagatomyia (1), Chrysops (3), Atylotus (2), Haematopota (2), Hybomitra (2), Isshikia (1), and Tabanus (5).
\end{abstract}

\section{INTRODUCTION}

The female terminalia of the Tabanidae are well known as Stuckenberg (1973: 658) stated that "see the many figures given by Mackerras, 1954, 1955, and subsequent papers, and by Bonhag, 1951, and Bromley, 1926 ", but few species of the Japanese Tabanidae is studied in this respect.

This paper is a part of our work on the female terminalia of the lower Brachycera projected as a sequel to the two papers entitled "Definition of Coenomyiidae" (Nagatomi, 1975) and "Classification of lower Brachycera" (Nagatomi, 1976).

For female terminalia of the Solvidae (=Xylomyidae), Xylophagidae s. lat. (Ra. chiceridae, Xylophagidae, Coenomyiidae and Exeretoneuridae), Rhagionidae s. lat. (Pelecorhynchidae and Rhagionidae), Athericidae and Vermileonidae see Nagatomi and Iwata (1976) and for those of Stratiomyidae and Pantophthalmidae see Nagatomi and Iwata (in preparation).

In the illustrations, the genital fork and the portions represented by the large broken-lines may not be exactly drawn and

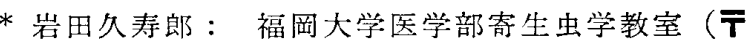
814 福岡市西区大字七隈 34)

** 永富 昭: 鹿児島大学農学部害虫学教室 ( $\boldsymbol{T} 890$ 鹿児島市郡元 1 丁目 21-24) the following abbreviations are used: $\mathrm{C}$ : cercus; $\mathrm{G}$ : genital fork (=genital furca); $\mathrm{T}$ $7-10$ : Terga $7-10$.

\section{CHARACTERS OF FAMILY}

Abdomen without a telescope ovipositor. Cercus 1-segmented and in general roughly as wide as long. In sternum 10, posterior margin convex and usually rounded. Tergum 10 elongate transversely and usually divided into a pair which are connected with each other or nearly so. Tergum 9 also divided into a pair which are widely separated from each other and much smaller than tergum 10, but that of Pangoniinae not divided and in some species (according to literature, e.g. Mackerras, 1956, 1960) larger than tergum 10. Sternum 8 in general roughly as wide as long and in many species roughly star-like. Tergum 8 much smaller than tergum 7 and usually wider than sternum 8. Tergum 7 , as well as tergum 8 , much wider than long. Intersegmental membrane between terga 7 and 8 short or hardly visible.

The female terminalia of Tabanidae are similar to those of Athericidae. The tergum 9 of Tabanidae is divided into a pair and much smaller than tergum 10 but that of Pangoniinae is not divided and in some species larger than tergum 10 as in the 
Athericidae. The mid-distal part of genital fork in Tabanidae is not produced forward (towards the base of abdomen), although that in some species of Pangoniinae (see Figs. 182 and 183 of Mackerras, 1960 : 143) is similar to some extent exceptionally to that in the genus Atrichops of Athericidae.

\section{CHARACTERS OF SUbFAMILIES AND GENERA}

According to Mackerras (1956: 398), (1) the tergum 9 is a transverse bar in Pangoniinae but divided and widely separated triangular plates in Chrysopinae and Tabaninae and (2) the caudal ends of spermathecal ducts have no expansions in Pangoniinae and Chrysopinae but have mushroom-shaped expansions in Tabaninae.

The species examined are too small in number and it is uncertain to us at the present that the definite distinguishing characters are present among the genera.

Mackerras (1956: 397) stated that "they [= genitalia] do not usually help in discriminating between genera or species. There are a few exceptions however, and these are occasionally so useful that dissection, at least of Pangoniinae, would always seem to be justified".

\section{SubFAMILY PANGONIINAE}

\section{Genus Stonemyia Brennen, 1935}

Stonemyia yezoensis (Shiraki, 1918) (Fig. 1): Posterior margin of cercus bluntly pointed to some extent; tergum 10 trapezoid and with inner margin shorter than outer margin; tergum 9 is thin at middle but appears to be not divided into a pair; sternum 8 distinctly wider than long, widest at middle, with posterior margin distinctly concave, and with anterior margin nearly straight; tergum 8 roughly as wide as sternum 8 .

Specimens examined : 2 우, Mt. Kirishima, Satsuma, 29. vii. 1962, A. Nagatomi.

\section{SUBFAMILy CHRYSOPINAE}

\section{Genus Nagatomyia Murdoch et Takahasi, 1961}

Nagatomyia melanica Murdoch et Taka-

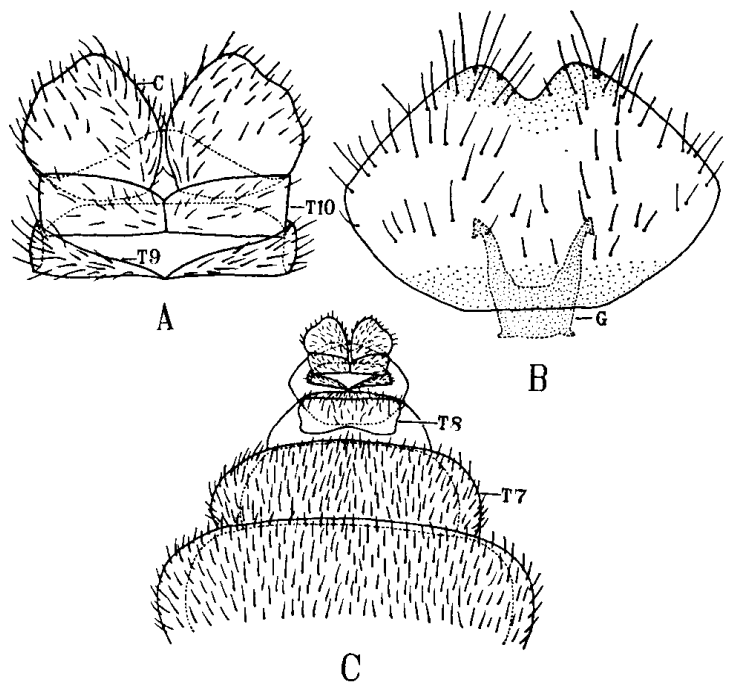

Fig. 1 Stonemyia yezoensis Shiraki, 우 (A : Terga 9-10 and cercus, dorsal view ; $\mathrm{B}$ : Sternum 8 , ventral view; $\mathrm{C}$ : Posterior part of abdomen, dorsal view (Explanations of $\mathrm{A}-\mathrm{C}$ are common with Figs. 2-17).

hasi, 1961 (Fig. 2): Cercus comparatively long and its postero-outer part rather angular; tergum 10 appears to be tapering outward; tergum 9 very small, triangular, and tapering inward; sternum 8 roughly star-like, and somewhat wider than long (1.3 times based on 1 individual), with posterior margin shallowly but distinctly concave.

Specimen examined: 1 우, Hataganaru, Ôginosen, Tajima (Hyogo-Pref.), 22. vii. 1959, A. Nagatomi.

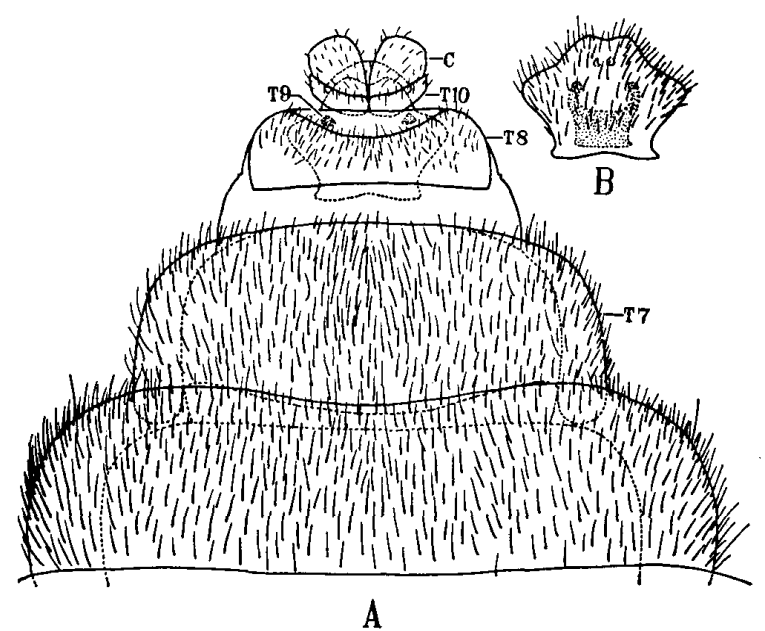

Fig. 2 Nagatomyia melanica Murdoch et Takahasi, 우. 


\section{Genus Chrysops Meigen, 1803}

The common characters to the 3 species, basalis, japonicus, and suavis are as follows: Posterior margin of cercus rounded; tergum 10 triangular or roughly so but not so sharply pointed at outer part; tergum 9 is tapering inward and its anterior margin appears to be gently concave; sternum 8 not star-like and widest near base.

Chrysops basalis Shiraki, 1918 (Fig. 3): Cercus comparatively long; in sternum 8, lateral margin slightly concave behind middle and posterior margin widely and distinctly concave at middle.

Specimen examined: 1 오, Iwate Pref., 16. viii. 1970, H. Hayakawa.

Chrysops japonicus Wiedemann, 1833 (Fig. 4): Cercus comparatively short; sternum 8 (except anterior margin) rounded.

Specimens examined: 1 우, Eboshidake, Taniyama, Satsuma, 17. iv. 1965, A. Tanaka; 1 오, Terayama, Kagoshima City,

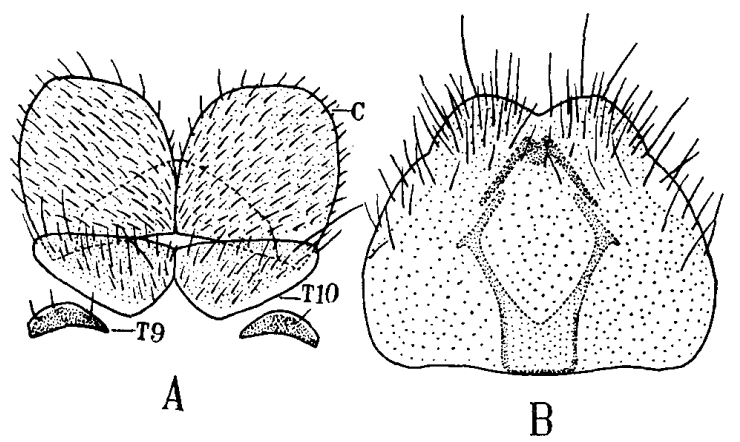

Fig. 3 Chrysops basalis Shiraki, 우.

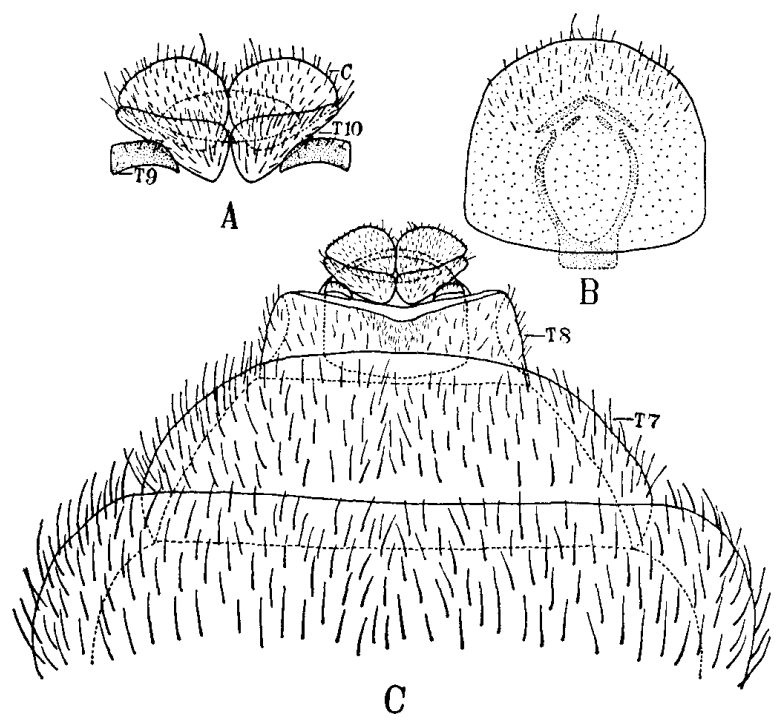

Fig. 4 Chrysops japonicus Wiedemann, 우.
27. iii. 1966, A. Tanaka.

Chrysops suavis Loew, 1858 (Fig. 5): Posterior margin of sterum 8 appears to be slightly concave.

Specimen examined: 1 우, Ono-cho, Kagoshima City, 22. iv. 1964, A. Tanaka.

\section{SUBFAMILY TABANINAE}

\section{Genus Atylotus Osten-Sacken, 1876}

Atylotus horvathi (Szilády, 1926) (Fig. 6):

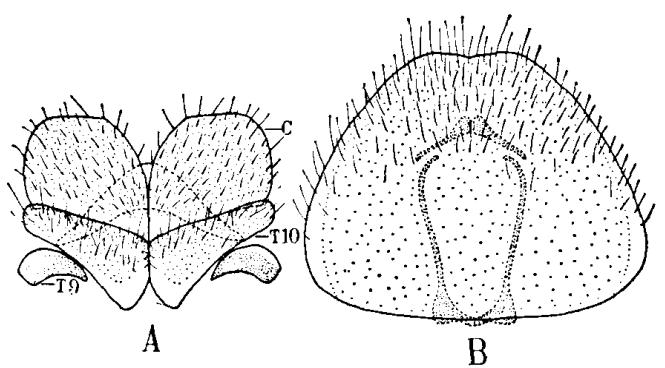

Fig. 5 Chrysops suavis Loew, 오.

Cercus comparatively long and with posterior margin rounded; tergum 10 rectangular; tergum 9 short and triangular; sternum 8 roughly star-like and with posterior margin shallowly but distinctly concave.

Specimen examined: 1 우, Uearata, Kagoshima City, 4. ix. 1966, A. Tanaka.

Atylotus sp. (Fig. 7) (this species will be

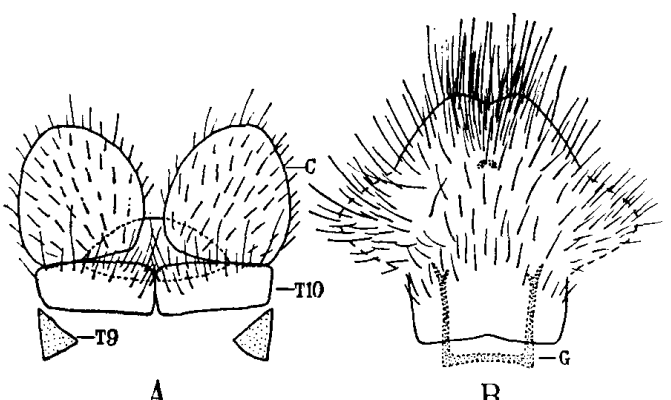

$A$

$\mathrm{B}$

Fig. 6 Atylotus horvathi Szilády, 우.

described as new to science by Dr. Hirosi Takahasi): Cercus wider than long.

Specimen examined: 1으, Takarajima, Tokara Islands, 20. vii. 1964, S. Ohga.

\section{Genus Haematopota Meigen, 1803}

Haematopota rufipennis Bigot, 1891 (Fig. 8): Cercus with posterior margin rounded; tergum 10 roughly rectangular and comparatively long; tergum 9 roughly triangular, tapering inward, and rather stout; sternum 


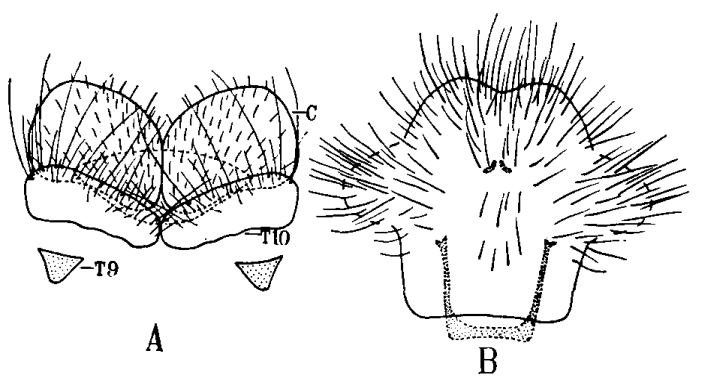

Fig. 7 'Atylotus sp., 오.

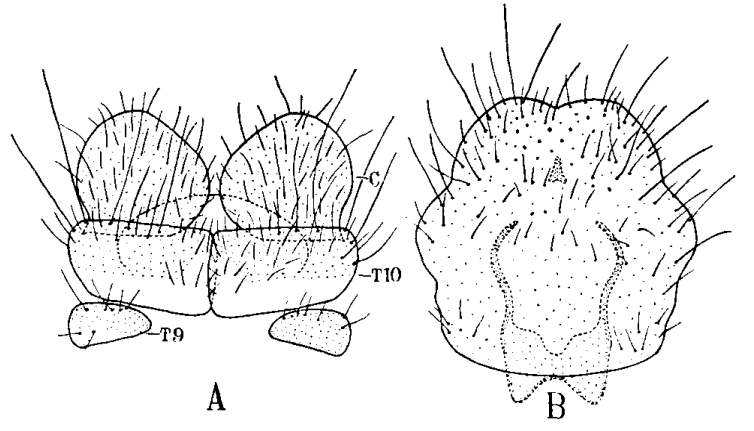

Fig. 8 Haematopota rufipennis Bigot, 우.

8 roughly star-like.

Specimen examined: 1우, Iwate Pref., 30. vi. 1971, H. Hayakawa.

Haematopota tristis Bigot, 1891 (Fig. 9): Cercus with posterior margin bluntly pointed to some extent ; tergum 10 roughly rectangular or trapezoid, and rather short; tergum

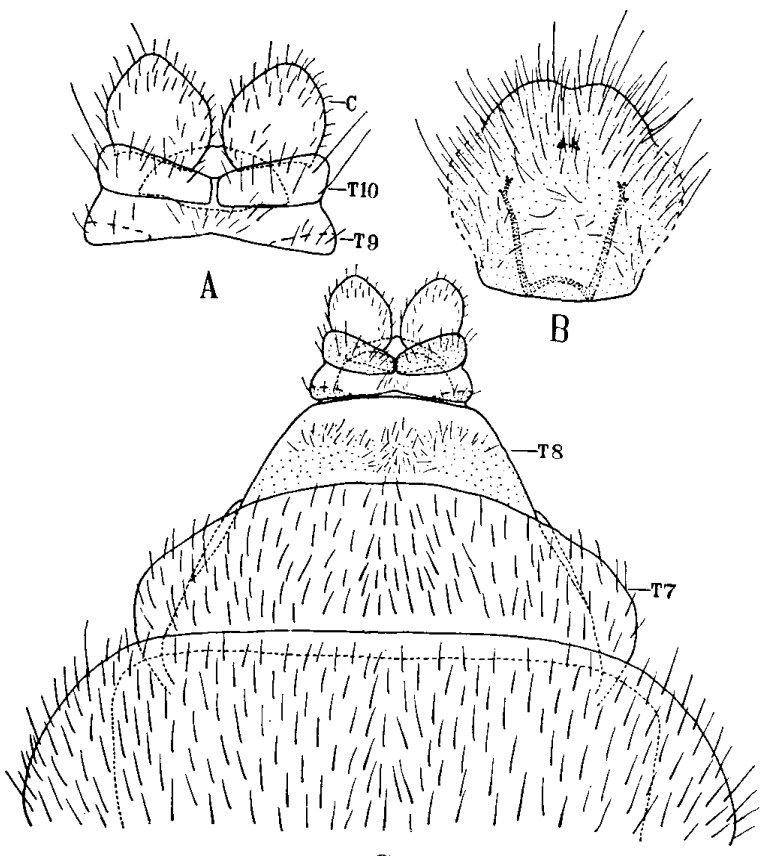

$\mathrm{C}$

Fig. 9 Haematopota tristis Bigot, 우.

9 roughly triangular, tapering inward, and rather slender; sternum 8 roughly star-like. [in the specimen figured, (a) a transparent membrane and (b) a pair of chitinous, triangular sclerites are seen before tergum 10 and it is probable that (a) is intersegmental membrane and (b) are tergum 9]

Specimens examined : 2 우, Kushiro, Hokkaido, 9. viii. 1967, K. Kanmiya.

\section{Genus Hybomitra Enderlein, 1922}

Hybomitra hirticeps (Loew, 1858) (Fig. 10): Cercus comparatively wide and with point between lateral and posterior margins rounded; tergum 10 roughly rectangular; tergum 9 triangular and tapering inward; sternum 8 widest behind middle and with posterior margin slightly concave.

Specimen examined: 1 우, Iwate Pref., 5. vi. 1970, H. Hayakawa.

Hybomitra jersey (Takahasi, 1950) (Fig. 11): Cercus comparatively wide [in the specimen figured, outer margin appears to be bent inward]; tergum 10 roughly rectangular; tergum 9 triangular and tapering inward; sternum 8 widest about at middle and with posterior margin shallowly but distinctly concave.

Specimen examined: 1 우, Iwate Pref., 10. vi. 1969, H. Hayakawa.

\section{Genus Isshikia Shiraki, 1918}

Isshikia yajimai Murdoch et Takahasi, 1961

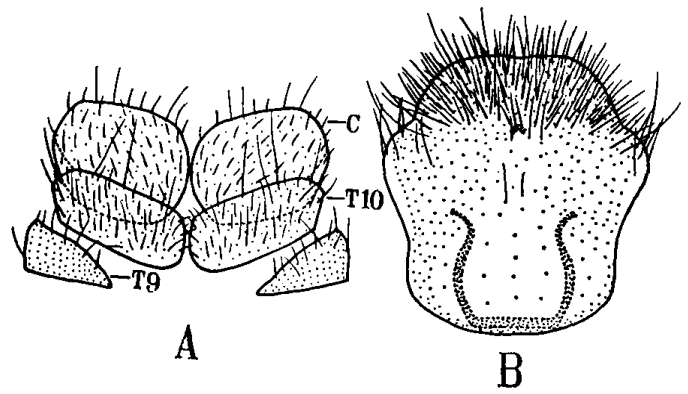

Fig. 10 Hybomitra hirticeps Loew, 오.

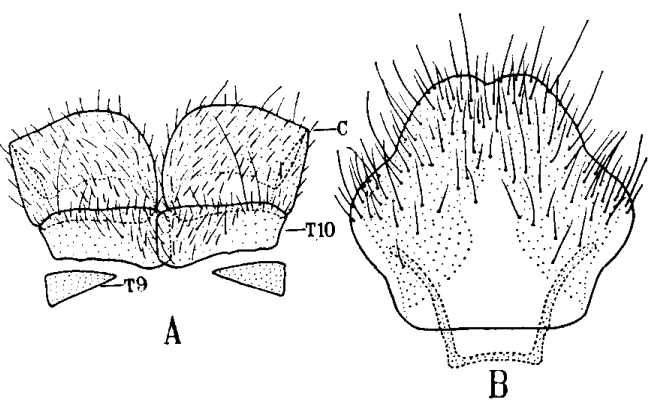

Fig. 11 Hybomitra jersey Takahasi, 우. 




Fig. 12 Isshikia yajimai Murdoch et Takahasi, 우.

(Fig. 12): Cercus comparatively long and with posterior margin rounded; tergum 10 triangular, tapering outward, and with inner margin long; tergum 9 triangular and tapering inward; in sternum 8 which is wide, posterior margin is concave at middle, lateral margin is concave behind middle, and anterior margin appears to be rounded.

Specimens examined : 1 ㅇ, Momiki, Gokanosho, Kumamoto Pref., 19. vii. 1966, A. Tanaka; 1 ㅇ, Momiki, Gokanosho, 20. vii. 1966, K. Kanmiya.

\section{Genus Tabanus Linnaeus, 1758}

Tabanus chrysurus Loew, 1858 (Fig. 13): Cercus comparatively wide and with posterior margin nearly straight; tergum 10 triangular, bluntly pointed at outer part, and with inner margin long; tergum 9

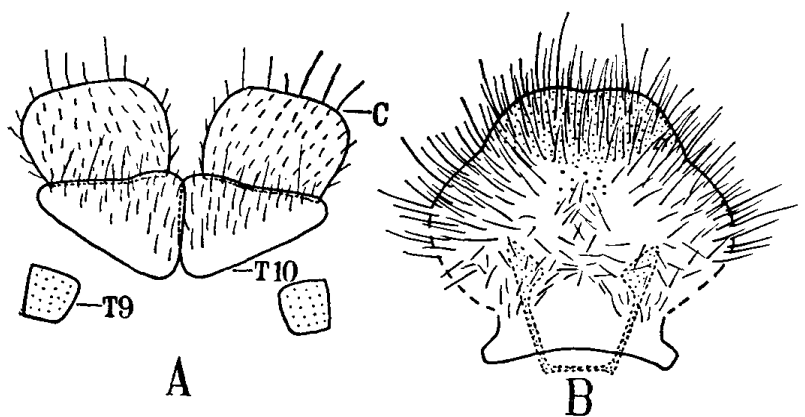

Fig. 13 Tabanus chrysurus Loew, 우. rectangular, small, and about as wide as long; sternum 8 with posterior margin slightly concave.

Specimen examined: 1우, Taradake, Nagasaki Pref., 11. viii. 1964, H. Shima.

Tabanus fulvimediodes Shiraki, 1918 (Fig. 14): Cercus with posterior margin rounded and somewhat produced; tergum 10 not triangular and with outer margin rounded and longer than inner margin; tergum 9 triangular, tapering inward, and stout; sternum 8 with posterior margin widely and rather deeply concave.

Specimens examined : 2 우, Momiki, Gokanosho, Kumamoto Pref., 19. vii. 1966, A. Tanaka.

Tabanus iyoensis Shiraki 1918 (Fig. 15): Cercus with posterior margin rounded but not produced; tergum 10 rectangular and

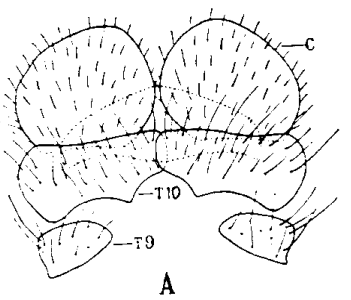

Fig. 14 Tabanus fulvimediodes Shiraki, 오. 


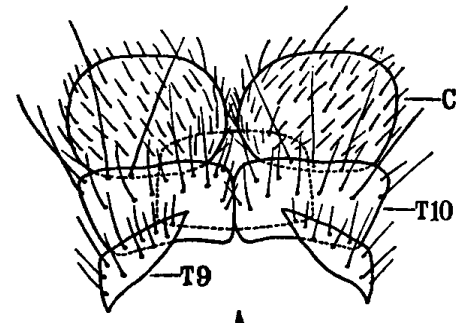

A

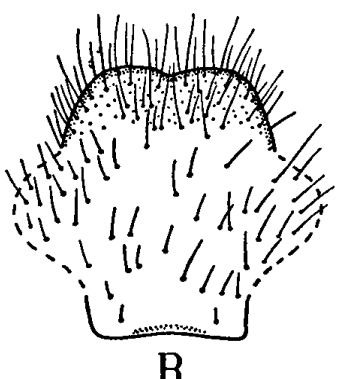

B
Fig. 15 Tabanus iyoensis Shiraki, 우.
Cercus with posterior margin rounded and produced; tergum 10 with inner and outer margins long; tergum 9 triangular, tapering inward, and with outer margin long; sternum 8 with posterior margin shallowly concave.

Specimen examined: 1 우, Yunono, Mt. Kirishima, Satsuma, 1. viii. 1959, H. Maebara.

Tabanus sapporensis Shiraki, 1918 (Fig. 17):

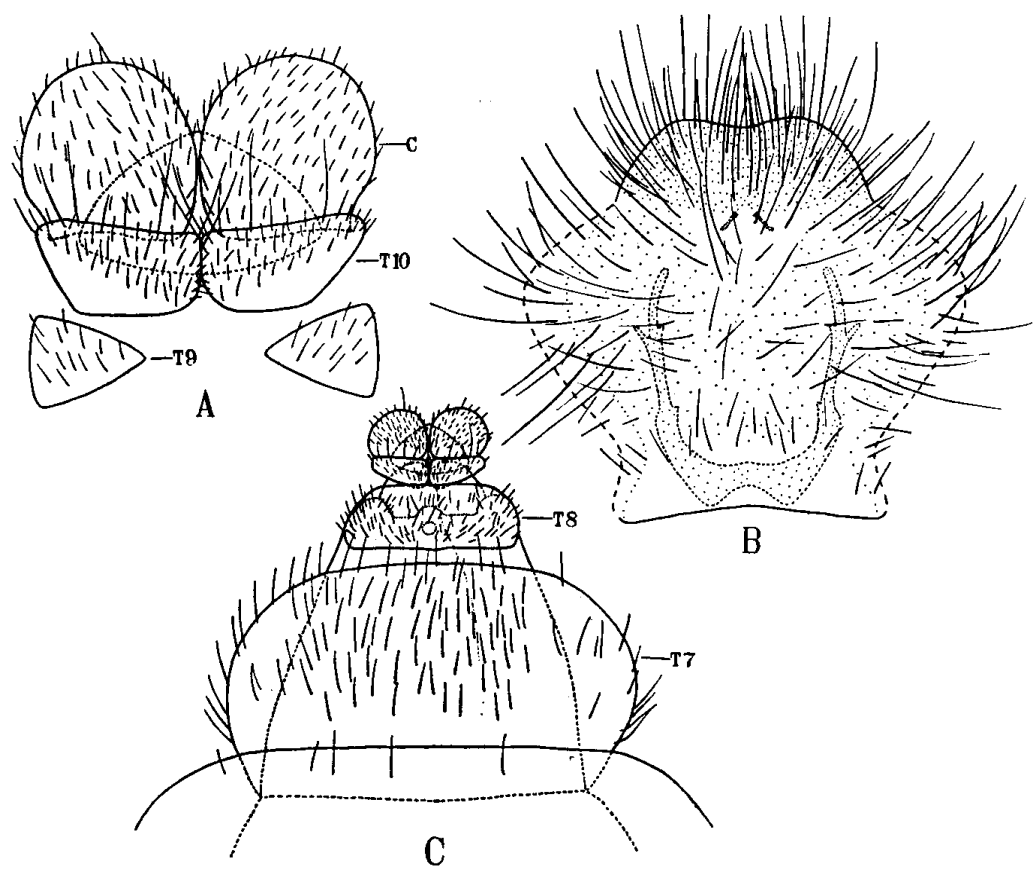

Fig. 16 Tabanus rufidens Bigot, 오.

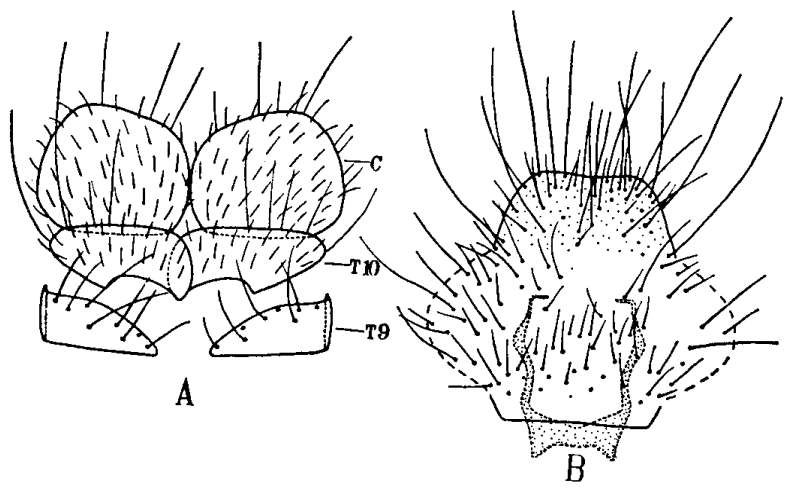

Fig. 17 Tabanus sapporensis Shiraki, 우.

with inner and outer margins rather long; tergum 9 triangular, tapering inward, and slender; sternum 8 with posterior margin slightly concave.

Specimens examined: 2 , , Senpirotaki, near Mt. Shibi, Satsuma, 14. viii. 1965, K. Hashimoto.

Tabanus rufidens (Bigot, 1887) (Fig. 16):
Cercus with posterior margin rounded and somewhat produced; tergum 10 with outer part bluntly pointed; tergum 9 triangular, tapering inward, and with anterior margin long; sternum 8 with posterior margin scarcely concave.

Specimen examined: 1 우, Iwate Pref., 14. viii. 1971, H. Hayakawa.

\section{ACKNOWLEDGEMENTS}

We are much indebted, to $\mathrm{Mr}$. Hirofumi Hayakawa (Tôhoku National Agricultural Experiment Station, Morioka) for the identification of the material examined and the gift of some specimens and to Mr. Akira Tanaka (Ôsumi Branch of Kagoshima Agricultural Experiment Station, Kanoya), Mr. Hiroshi Shima (Kyushu University, Fukuoka), Mr. Kôji Hashimoto (Tarumizu High School, Kagoshima Pref.), and Mr. Kenkichi Kanmiya (Kurume University, Kurume) for the gift of specimens. 
One of us (Iwata) expresses his sincere thanks to Professor Ichiro Miyazaki and Dr. Teiji Kifune (Fukuoka University, Fukuoka) for their encouragement and support.

\section{REFERENCES}

Mackerras, I. M. (1956-61) : The Tabanidae (Diptera) of Australia. Aust. J. Zool., 4 : 376443, $8: 1-152,9: 827-905$.

Murdoch, W. P. and Takahasi, H. (1969): The female Tabanidae of Japan, Korea and Manchuria (Diptera). Mem. Ent. Soc. Wash., No. 6. $230 \mathrm{p}$.

Nagatomi, A. (1975) : Definition of Coenomyiidae (Diptera). Proc. Japan Acad., 51 : 452-466.

Nagatomi, A. (1976) Classification of lower Brachycera (Diptera). J. nat. Hist., in press.

Nagatomi, A. and Iwata, K. (1976): Female terminalia of lower Brachycera (Diptera). I.
Beitr. Ent. (Berlin), in press

Stuckenberg, B. R. (1973): The Athericidae, a new family in the lower Brachycera (Diptera). Ann. Natal Mus., 21 : 649-673.

Takahasi, H. (1962) : Fauna Japonica. Tabanidae (Insecta: Diptera). 143 p. Biogeographical Society of Japan, Tokyo.

\section{摘 要}

\section{日本産アブ科の 앙部生殖器}

Pangoniinae $の$ Stonemyia 属, Chrysopinae の Nagatomyia, Chrysops 両属, Tabaninae $の$ Atylotus, Haematopota, Hybomitra, Isshikia, Tabanus 05 属, 合計 17 種の 오外部生殖器を記載図示した。

アブ科に近縁の諸科の外部生殖器との比較が一つの目 的であるが，これらの諸科については別に発表予定であ る. 